\title{
モチ米澱粉の熱水ナノスケール微細化
}

\author{
吉岡泰嗣 ${ }^{1}$, 清水直人 ${ }^{2, \dagger}$ \\ ${ }^{1}$ 北海道大学大学院農学院, ${ }^{2}$ 北海道大学大学院農学研究院
}

\section{Characterization of the Nanoscale Processing of Waxy Rice Starch Using Compressed Hot Water}

\author{
Hirotsugu YOSHIOKA ${ }^{1}$, Naoto SHIMIZU ${ }^{2, \dagger}$ \\ Graduate School of Agriculture, Hokkaido University, \\ Kita 9 Nishi 9, Kita-ku, Sapporo, Hokkaido 060-8589, Japan
}

\begin{abstract}
Nanoscale waxy rice starch particles were prepared in compressed hot water, and the effects of the concentration of waxy rice starch dispersion, the pressure and temperature of the compressed hot water on mean particle size and particle size distribution were investigated. Particle size and particle size distribution of the waxy rice starch nanoparticles were measured by dynamic light scattering. Mean particle size was found to depend on the preparation conditions. The smallest average particle size of $150.4 \mathrm{~nm}$ was obtained with a starch concentration of $0.1 \%(\mathrm{w} / \mathrm{w})$, an initial pressure of 3.0 $\mathrm{MPa}$, and a final temperature of $180^{\circ} \mathrm{C}$. It is suggested that particle size can be controlled by the preparation conditions. In addition, any sample prepared in compressed hot water tends to have a particle size distribution spanning less than $100 \mathrm{~nm}$. The use of compressed hot water is also effective for preparing waxy rice starch nanodispersion with nanoparticles smaller than $100 \mathrm{~nm}$. Furthermore, we have attempted to determine the reaction field of compressed hot water by the ionic product.
\end{abstract}

Keywords: waxy rice starch, nanoparticle, compressed hot water, ionic product

1. 緒言

持続可能な社会の実現には，バイオマス資源の有効 活用が急務である。そこで，現在バイオマス資源のナ ノスケール微細化の様々な研究が行われている。物質 はナノ粒子化されることによって別の性質を発揮する ことが知られている。そのためバイオマス資源をナ， 粒子化することでドラッグデリバリシステム，食品包 装資材，ナノコンポジット材料などの高付加価值な素 材を提供し，バイオマス利用の質的，量的向上に寄与 することができるのではないかと考えられる [1-8].

澱粉は自然界に存在する代表的な多糖類であり，存 在量が多く, 安価であり, その機能性から食品, 製紙, 薬品担体などさまざまな分野で利用されている [9-11]. その中で，モ千米澱粉は難分解性の多糖類として知ら れており，多糖類のナノスケール微細化のモデルの 1 つになると考えられる.

(受付 2013 年 12 月 25 日, 受理 2014 年 4 月 25 日)

1 于 060-8589 札幌市北区北 9 条西 9 丁目

2 于 060-8589 札幌市北区北 9 条西 9 丁目

Fax: 011-706-3848, E-mail: shimizu@bpe.agr.hokudai.ac.jp
これまで，澱粉のナノスケール微細化は様々な方法 で試行されてきた，酵素を利用した方法では，澱粉一 $\mathrm{n}$-ブタノール複合体を $\alpha$-アミラーゼを用いて加水分解 して，粒径約 20〜 50 $\mathrm{nm}$ の澱粉ナノ粒子を得たが，澱 粉の大半が加水分解の過程で失われ，澱粉ナノ粒子の 収率は非常に低かった。また，高圧均質化法により約 $100 \%$ の生成率でトウモロコシ澱粉のナノ粒子を作った と報告されているが，この処理方法では粒子径を制御 できなかった。さらに、ジェットミルなどを用いた乾 式粉砕法では粉粒体の最小平均粒子径は数マイクロ メートルであった。湿式媒体攂拌ミルを用いた方法で は平均粒子径 $100 \mathrm{~nm}$ 前後の粒子を得たものの, 粉砕時 間が 168 時間を要している [1,2,11]，そこで，湿式場の 過酷な条件で澱粉鎖の加水分解を行うことで結晶構造 を破壊し，平均粒子径をナノメートルまで小さくする ためにナノスケール微細化の手段として加圧熱水を用 いた. 加圧熱水は亜臨界水を用いた反応場であり, 温度. 圧力を操作することで容易に水のイオン積を増加する ことができ，物質の分解反応を促すことができる．水 のイオン積については超臨界領域までの広範囲に適用 できる計算式として提案されている Marshall-Franck 
の式を用いて温度，圧力により求めることができる [12-15].

そこで，本報では澱粉の濃度，反応場の温度，圧力 などの調製条件による澱粉ナノ粒子の性質（平均粒子 径，粒度分布）の違いを観察し，加圧熱水を用いたモ チ米澱粉のナノスケール微細化特性について明らかに することを目的とした，また，Marshall-Franck の式 を用いて温度と圧力からイオン積を求め, 加圧熱水の 反応場のイオン積と澱粉ナノ粒子の平均粒子径との関 係を調べた。

\section{2. 供試材料と実験方法}

\section{1 供試材料}

供試材料として，モチ米澱粉（モチール B，平均粒 径 4〜 $5 \mu \mathrm{m}$ ，上越スターチ(株)）を用いた。

\section{2 澱粉ナノ粒子分散系の調製}

加圧熱水による澱粉ナノ粒子分散系の反応容器を Fig. 1 に示し，澱粉ナノ粒子分散系を下記の操作により 調製した. 而圧容器（ステンレス鋼容器: 内径 $4.8 \mathrm{~cm}$, テフロン樹脂製内筒：内径 $3.6 \mathrm{~cm}$ ，高さ $12 \mathrm{~cm} ）$ に純 水 $50 \mathrm{ml}$ とモチ米澱粉を投入した。分散液の澱粉濃度 を 0.05, 0.1, 0.3, 0.5, 1\% (w/w)の 5 水準とした. 次に, 窒素ガスを用いて耐圧容器内の空気を置換し, 容器内

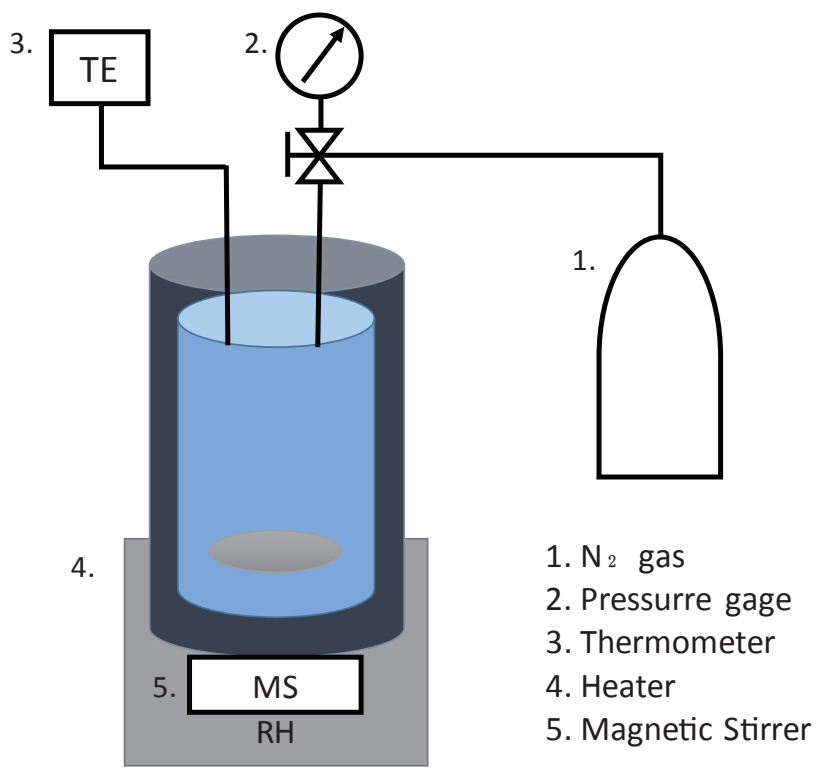

Fig. 1 Nanodispersion preparation reactor.
圧力を調整して，2.0，2.5，3.0 $\mathrm{MPa} の 3$ 水準の初期圧 力条件を設定した。有機合成装置 (Chemi Station PPV-3000, 東京理化器械(株)）を用いて澱粉溶液の加 熱, 撌拌を行い, 反応容器内の温度が $140,160,180^{\circ} \mathrm{C}$ になるまで加熱，覧拌した。覮拌は磁気式スターラに より, 回転数 $1,000 \mathrm{rpm}$ で行った. 反応時間は, 容器 内の試料が設定温度に達するまでとし, 設定温度 140 , 160， $180^{\circ} \mathrm{C}$ に打いて $3000 ， 3600 ， 4000$ 秒間であった。 加熱, 覮找の後, 有機合成装置から而圧容器を取り出し, $5{ }^{\circ} \mathrm{C}$ の水で冷却し, 澱粉ナノ粒子分散系を採取した. Table 1 に 9 水準の調製条件をとりまとめて示した。 ま た，反応中の温度変化を $\mathrm{K}$ 型熱電対により計測し，圧 力変化を圧力計を用いて計測した.

\section{3 平均粒子径・粒度分布測定}

採取した澱粉ナノ粒子分散系をシリンジを用いてフ ローセルに注入し, ゼータ電位粒度分布測定装置 (Delsa Nano HC， ベックマン・コールター(株)）を用いて動 的光散乱法により溶液内の澱粉粒子の散乱強度を測定 し, 平均粒子径と粒度分布を求めた。動的光散乱法は 溶液や懸濁液中でブラウン運動している粒子にレー ザー光を照射し，粒子からの散乱光のゆらぎを感知す ることで平均粒子径，粒度分布を測定する方法である [16].

\section{$2.4 \operatorname{span}$ による粒度分布の評価}

次式で表される相対 span 值を用いて粒度分布の広が りを評価した。

$$
\operatorname{span}=\frac{D_{90}-D_{10}}{D_{50}}
$$

$D_{\mathrm{n}}$ : 累積頻度分布 $\mathrm{n} \%$ に打ける平均粒子径 span は相対的に粒度分布の広がりを示す数值であり， その数值が大きいほど粒度分布の広がりが大きく, 数 值が小さいほど粒度分布の広がりが小さく平均粒子径 が均一な試料であることを示す [17].

\section{5 加圧熱水とイオン積}

加圧熱水の反応場は亜臨界水を用いたものであり, 温度・圧力を操作することでイオン積を増加させるこ とができる。亜臨界水は常圧における沸点から臨界温 度 $\left(374^{\circ} \mathrm{C}\right)$ までの温度域で加圧することにより液体状 態を保った流体のことであり, 常温常圧の流体とは異 なった性質をもつ. 常温常圧の水に比べて比誘電率が

Table 1 Experimental condition.

\begin{tabular}{cccc}
\hline Concentration $(\%, w / w)$ & Pressure $(\mathrm{MPa})$ & Temperature $\left({ }^{\circ} \mathrm{C}\right)$ & Time $(\mathrm{s})$ \\
\hline $0.05,0.1,0.3,0.5,1$ & 2.5 & 180 & 4000 \\
0.1 & $2.0,2.5,3.0$ & 180 & 4000 \\
0.1 & 2.5 & $140,160,180$ & $3000,3600,4000$ \\
\hline
\end{tabular}


小さく，有機溶媒に似た性質を示し，亜臨界水は常温 より高濃度に疎水性物質を溶解する [14]．さらに，水 素イオンと水酸化物イオンの濃度の積であるイオン積 が大きな值を示す。室温に打ける水のイオン積は $10^{-14}$ $(\mathrm{mol} / \mathrm{kg})^{2}$ 程度であるが， $200^{\circ} \mathrm{C}$ またはそれ以上の温度 では $10^{-11}(\mathrm{~mol} / \mathrm{kg})^{2}$ となり，約 1000 倍も大きくなり， 亜臨界水が酸または塩基触媒として作用する可能性が 予想される $[14,15]$. イオン積を求める式として Marshall-Franckの式が超臨界領域までの広範囲に適 用できる計算式として提案されている，反応場の到達 温度と到達圧力から，下記の Marshall-Franck の式を 用いて加圧熱水のイオン積を求めた [13,15].

$$
\begin{aligned}
\log K_{w}= & A+B / T+C / T^{2}+D / T^{3} \\
& +\left(E+F / T+G / T^{2}\right) \log \rho_{w}
\end{aligned}
$$

$K_{w}$ : 水の解離定数 $(\mathrm{mol} / \mathrm{kg})^{2}, \rho_{w}$ : 水の密度 $\left(\mathrm{g} / \mathrm{cm}^{3}\right)$, $T:$ 温度 $(\mathrm{K}), A:-4.098$,

$$
\begin{array}{ll}
B:-3.2452 \times 10^{3}(\mathrm{~K}), & C: 2.2362 \times 10^{5}\left(\mathrm{~K}^{2}\right), \\
D:-3.984 \times 10^{7}\left(\mathrm{~K}^{3}\right), & E: 13.957, \\
F:-1.2623 \times 10^{3}(\mathrm{~K}), & G: 8.5641 \times 10^{5}\left(\mathrm{~K}^{2}\right)
\end{array}
$$

\section{3. 結果及び考察}

\section{1 加圧熱水場の温度及び圧力変化}

澱粉ナノ粒子調製装置に打ける反応容器内の温度変 化と圧力変化の一例を Fig. 2 に示す. 試料の温度は室 温から緩やかに上昇し， $180^{\circ} \mathrm{C}$ まで達する時間は約 4000 秒であった。加えて, 到達圧力については, $3.5 \mathrm{MPa}$ (初 期圧力 $2.0 \mathrm{MPa}$ ) $4.5 \mathrm{MPa}$ (初期圧力 $2.5 \mathrm{MPa}$ ), 5.0 $\mathrm{MPa}$ (初期圧力 $3.0 \mathrm{MPa}$ ） に達した。初期圧力が違つ ても温度はほぼ同じように上昇した。

\section{2 加圧熱水の澱粉溶液への効果}

加圧熱水の効果を知るため, 加圧熱水調製試料に加 えて，圧力は大気圧，調製温度は $100^{\circ} \mathrm{C}$ に設定して調製 した試料の粒度分布を Fig. 3 に示す。大気圧 $-100^{\circ} \mathrm{C}$ で

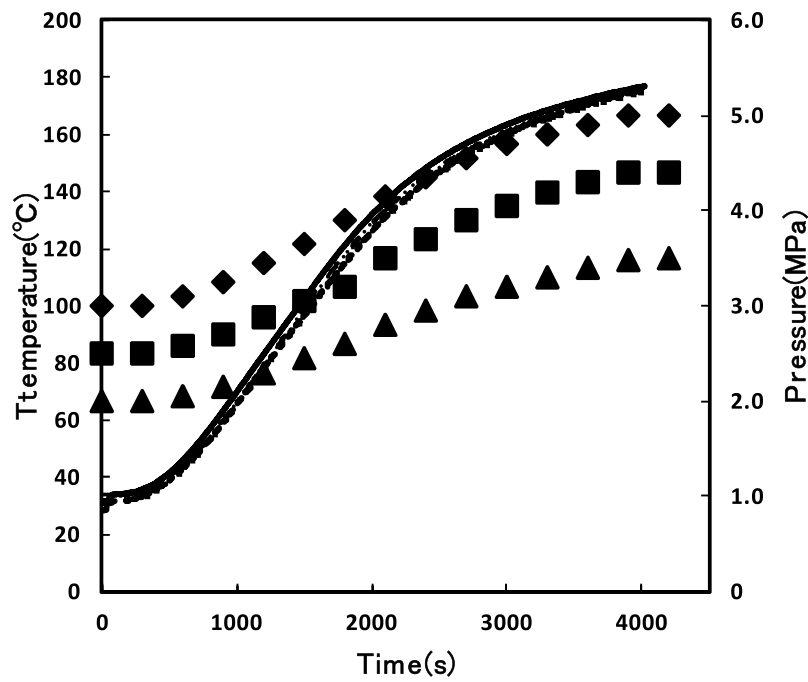

Fig. 2 Temperature and pressure changes in compressed hot water. Temperatures change in initial pressures of $2.0 \mathrm{MPa}$ (--), 2.5 $\mathrm{MPa}(-)$ and $3.0 \mathrm{MPa}(---)$; pressures change in initial pressures of $2.0 \mathrm{MPa}(\boldsymbol{\Delta}), 2.5 \mathrm{MPa}(\boldsymbol{\square}), 3.0 \mathrm{MPa}(\bullet)$

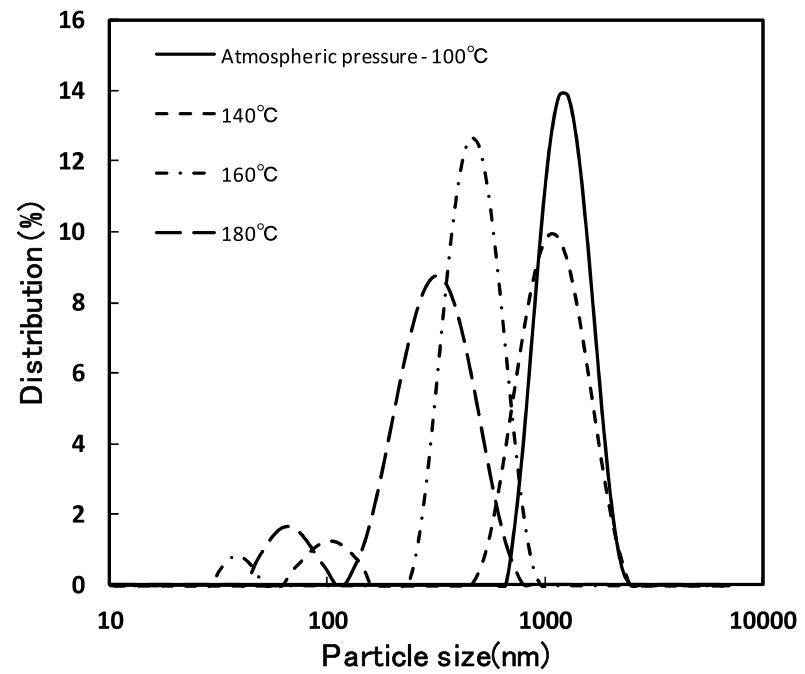

Fig. 3 Particle distribution of waxy rice starch nanodispersion. Hot water with a temperature of $100^{\circ} \mathrm{C}$ and an atmospheric pressure; The compressed hot water with an initial pressure of $2.5 \mathrm{MPa}$ and final temperatures of $140^{\circ} \mathrm{C}, 160^{\circ} \mathrm{C}, 180^{\circ} \mathrm{C}$.

Table 2 Mean particle size and span factors.

\begin{tabular}{cccc}
\hline Processing & & Mean particle size $(\mathrm{nm})$ & Span \\
\hline & $0.05 \%(\mathrm{w} / \mathrm{w})$ & 169.4 & 2.62 \\
Concentration & $0.10 \%(\mathrm{w} / \mathrm{w})$ & 217.3 & 1.23 \\
$\left(2.5 \mathrm{MPa}, 180^{\circ} \mathrm{C}\right)$ & $0.30 \%(\mathrm{w} / \mathrm{w})$ & 235.7 & 2.02 \\
& $0.50 \%(\mathrm{w} / \mathrm{w})$ & 244.4 & 2.55 \\
& $1.0 \%(\mathrm{w} / \mathrm{w})$ & 325.0 & 1.51 \\
\hline \multirow{2}{*}{ Pressure } & $2.0 \mathrm{MPa}$ & 318.7 & 2.18 \\
$\left(0.1 \%, 180^{\circ} \mathrm{C}\right)$ & $2.5 \mathrm{MPa}$ & 217.3 & 1.23 \\
& $3.0 \mathrm{MPa}$ & 150.4 & 1.80 \\
\hline \multirow{2}{*}{ Temperature } & $140^{\circ} \mathrm{C}$ & 530.2 & 1.01 \\
$(0.1 \%, 2.5 \mathrm{MPa})$ & $160^{\circ} \mathrm{C}$ & 344.0 & 0.75 \\
& $180^{\circ} \mathrm{C}$ & 217.3 & 1.23 \\
\hline Atmospheric pressure- $100^{\circ} \mathrm{C}$ & 965.5 & 0.67 \\
\hline
\end{tabular}


調製した試料の平均粒子径は $965.5 \mathrm{~nm}, \operatorname{span}$ 值が 0.67 と非常に小さく, 平均粒子径が均一であった（Table 2). 粒度分布をみると, 粒子の大半が $1000 \mathrm{~nm}$ 付近に集中 しており，700 nm 以下の領域に分布は認められなかっ た。加圧熱水で調製した試料の平均粒子径は大気圧 $-100^{\circ} \mathrm{C}$ で調製した試料に比べて格段に小さかった。粒 度分布を観ると，加圧熱水で調製した試料はいずれの 試料においても $100 \mathrm{~nm}$ 以下の領域に分布が確認され た. 大気压 $-100^{\circ} \mathrm{C}$ の試料では平均粒子径 $100 \mathrm{~nm}$ 以下 の小さな粒子が存在せず，加圧熱水を用いて調製した 試料に打いては粒子径 $100 \mathrm{~nm}$ 以下の小さな粒子の分布 が確認されたことから，粒子径が $100 \mathrm{~nm}$ 以下の小さな 粒子を含む澱粉ナノ粒子分散系を調製する手段として, 有用であることが示された。

さらに, 澱粉濃度 $0.1 \%(\mathrm{w} / \mathrm{w})$, 到達温度 $180^{\circ} \mathrm{C} に し$, 初期圧力を $2.0,2.5,3.0 \mathrm{MPa}$ の 3 水準で処理すること で, 加圧による平均粒子径, 粒度分布の違いを比較し た（Fig. 4 (b) ). 調製時の圧力が大きいほど粒子径が小 さくなる傾向にあった。初期圧力を $3.0 \mathrm{MPa}$ に設定し て調製した際には平均粒子径 $150 \mathrm{~nm}$ の澱粉ナノ粒子を 得ることができた。いずれの試料も大気圧 $-100^{\circ} \mathrm{C} て ゙$ 調 製した試料に比べて平均粒子径が格段に小さくなった。 大気压 $-100^{\circ} \mathrm{C}$ の試料に比べて加圧熱水で調製した試料 に扎いて span が大きくなり, 粒度分布の幅が広がった。 2.0, 2.5, 3.0 MPaの 3 水準に打いて加圧の違いにより span 值に差がなかったことから，圧力による粒度分布 の広がりに差は認められなかった. 初期圧力 $2.0,2.5,3.0$ $\mathrm{MPa}$ のいずれの处理においても粒子径 $100 \mathrm{~nm}$ 以下に 分布が認められ，初期圧力 $3.0 \mathrm{MPa}$ で調製したものにつ いては $100 \mathrm{~nm}$ 以下の累積頻度分布が $30 \%$ あったた。 加圧することで平均粒子径の小さい澱粉ナノ粒子分散 系を調製することができた。本研究において，同調製 条件で試料を調製した場合，平均粒子径，粒度分布に 多少の違いはあったが，それぞれの調製条件に打ける 平均粒子径，粒度分布の傾向は変わらなかった。

\section{3 濃度が平均粒子径・粒度分布に及ぼす影響}

初期圧力 $2.5 \mathrm{MPa}$ ，到達温度 $180^{\circ} \mathrm{C}$ に，澱粉濃度を $0.05,0.1,0.3,0.5,1.0 \%$ の 5 水準にして処理することで 澱粉の濃度による粒子の平均粒子径と span の変化を比 較した（Table 2)，澱粉が低濃度の試料ほど平均粒子径 が小さくなる傾向を示した (Fig. $4(\mathrm{a}))$. 澱粉濃度 $0.05 \%$ (w/w) に打いては，平均粒子径 $169.4 \mathrm{~nm}$ というように 粒子径が非常に小さかった。一方，spanの值について は澱粉濃度による有意差はなく，粒度分布の広がりの 違いは確認されなかった。いずれの試料においても粒 子径 $100 \mathrm{~nm}$ 以下に粒子の存在を認めた。澱粉濃度 $0.05 \%(\mathrm{w} / \mathrm{w})$ での処理においては，粒子径 $100 \mathrm{~nm}$ 以下 の累積頻度分布が約 $20 \%$ であった。澱粉ナノ分散系の
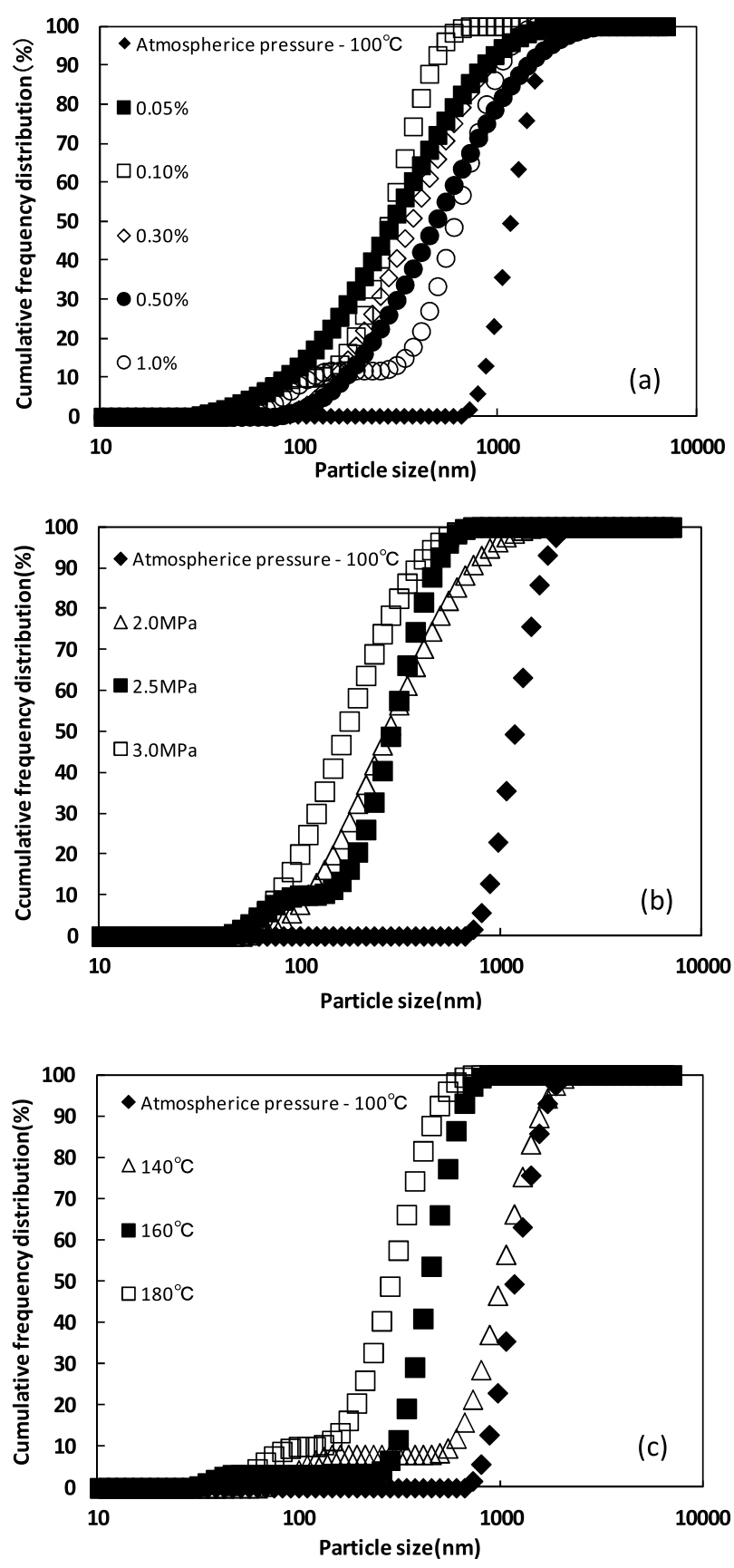

Fig. 4 Particle cumulative frequency distribution of waxy rice starch nanodispersion.

濃度が $1.0 \%(\mathrm{w} / \mathrm{w})$ までになると, 濃度 $0.05 \sim 0.5 \%(\mathrm{w} /$ w) の場合と比べて, 並進拡散係数や散乱強度 [18] が変 化したために，粒子径の值が若干大きく算出されたも のと考えられる。

\section{4 到達温度が平均粒子径・粒度分布に及ぼす影響}

濃度 $0.1 \%$, 初期圧力 $2.5 \mathrm{MPa}$ にし, 到達温度を 180 , $160,140^{\circ} \mathrm{C}$ の 3 水準で処理することで，加圧熱水場の温 度による粒度分布の違いを検討した（Fig． 4 (c))。熱水 の温度が高いほど平均粒子径が小さくなる傾向にあっ た (Table 2). 到達温度 $180^{\circ} \mathrm{C}$ で調製した試料では平均 
粒子径が $217.3 \mathrm{~nm}$ となった。大気圧 $-100^{\circ} \mathrm{C}$ で調製し た試料では span 值が最小值 0.67 であり, 加圧熱水で 調製した試料では span 值が大きくなり，粒度分布が広 くなった。到達温度 $180,160,140^{\circ} \mathrm{C}$ の 3 水準において span 值に温度による有意差がなく，到達温度による粒 度分布の広がりの違いは認められなかった。大気圧 $-100^{\circ} \mathrm{C}$ で調製した試料では $100 \mathrm{~nm}$ 以下に分布はなかっ たが，140，160， $180^{\circ} \mathrm{C}$ でのいずれの処理でも粒子径 $100 \mathrm{~nm}$ 以下に分布が認められた。調製温度が高いほど 澱粉鎖の切断が促進され，温度上昇により加圧熱水中 のイオン積が室温で大気圧下の約 400 倍まで増加し, 澱粉の加水分解を促したためであると考えられる.

\section{5 イオン積と平均粒子径の関係}

先に述べたように加圧熱水の反応場は带臨界水を用 いたものであり，温度・圧力を操作することでイオン 積が増加する．温度・圧力を操作することで解離され た水素イオン $\mathrm{H}^{+}$と水酸化物イオン $\mathrm{OH}^{-}$により澱粉の加 水分解を促進することができる $[11 ， 13-16]$. 反応場の 温度と圧力から，超臨界領域までの広範囲に適用でき る計算式として提案されている Marshall-Franck の式 を用いて加圧熱水のイオン積を求め，イオン積と平均 粒子径との関係について調べた. Table 3 に初期圧力 2.5 $\mathrm{MPa}-180^{\circ} \mathrm{C}, 160^{\circ} \mathrm{C}, 140^{\circ} \mathrm{C}$, 大気圧 $-100^{\circ} \mathrm{C}$ の各条件にお けるイオン積を示した。イオン積は大気圧 $-100^{\circ} \mathrm{C} に お ~$ いて $10^{-12.2591}(\mathrm{~mol} / \mathrm{kg})^{2}$ であり, $2.5 \mathrm{MPa}-180^{\circ} \mathrm{C} に$ 打い て $10^{-11.4148}(\mathrm{~mol} / \mathrm{kg})^{2}$ であった. Fig. 5 に水のイオン 積と澱粉の平均粒子径の関係を示した。澱粉の平均粒 子径は，水のイオン積が $10^{-12.2591}(\mathrm{~mol} / \mathrm{kg})^{2}$ の場合には 平均粒子径が $965.5 \mathrm{~nm}$, 水のイオン積が $10^{-11.4148}(\mathrm{~mol} /$ $\mathrm{kg})^{2}$ の場合には平均粒子径 $217.3 \mathrm{~nm}$ であった. 2.5 $\mathrm{MPa}-180^{\circ} \mathrm{C}, 2.5 \mathrm{MPa}-160^{\circ} \mathrm{C}, 2.5 \mathrm{MPa}-140^{\circ} \mathrm{C}$, 大気圧 - $100^{\circ} \mathrm{C}$ の 4 つ処理条件に打ける水のイオン積と澱粉 の平均粒子径の違いをまとめると，平均粒子径の変化 とイオン積の変化には負の相関 $\left(\mathrm{R}^{2}=0.99\right)$ があり, 水 のイオン積が大きいほど澱粉の平均粒子径が小さくな ることがわかった．水のイオン積が大きい場合には, 水から解離した水素イオン $\mathrm{H}^{+}$と水酸化物イオン $\mathrm{OH}^{-}$ により澱粉の加水分解が促進され，平均粒子径の小さ な澱粉粒子が加圧熱水によって調製されるものと考え られる.より高温，高圧の反応場を作ることで水のイ

Table 3 Experimental condition and ionic product.

\begin{tabular}{cc}
\hline \multicolumn{1}{c}{ Processing } & $\log (\mathrm{Kw})$ \\
\hline $2.5 \mathrm{MPa}-180^{\circ} \mathrm{C}(4.4 \mathrm{MPa})$ & -11.4148 \\
$2.5 \mathrm{MPa}-160^{\circ} \mathrm{C}(3.95 \mathrm{MPa})$ & -11.5466 \\
$2.5 \mathrm{MPa}-140^{\circ} \mathrm{C}(3.55 \mathrm{MPa})$ & -11.7534 \\
Atmospheric pressure- $100^{\circ} \mathrm{C}$ & -12.2591 \\
\hline
\end{tabular}

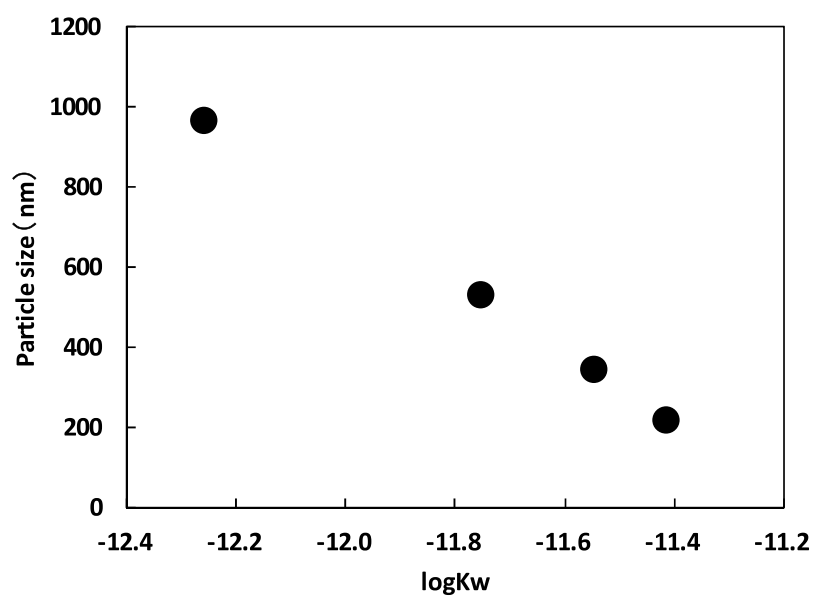

Fig. 5 Relation of ionic product and average particle size of waxy rice starch. Experimental condition: an initial pressure of $2.5 \mathrm{MPa}$ and temperatures of $140^{\circ} \mathrm{C}, 160^{\circ} \mathrm{C}$ and $180^{\circ} \mathrm{C}$; atmospheric pressure and temperature of $100^{\circ} \mathrm{C}$.

オン積を増加させ，澱粉粒子の平均粒子径をより小さ いものにできる可能性がある.

\section{4. 結 論}

本実験の操作範囲内において，澱粉の平均粒子径は 圧力・温度条件に依存し，澱粉濃度が低いほど平均粒 子径は小さくなり，加圧熱水反応場の圧力と温度が大 きいほど平均粒子径は小さくなった. 澱粉濃度 $0.1 \%$ (w/ w)，初期圧力 $3.0 \mathrm{MPa}$ ，到達温度 $180^{\circ} \mathrm{C}$ という調製条件 に打いて平均粒子径は $150.4 \mathrm{~nm}$ になり，粒子径 100 $\mathrm{nm}$ 以下の累積分布が約 $30 \%$ であり，本実験に打ける 最小の平均粒子径をもつ試料が得られた。本実験の操 作範囲において温度, 圧力, 澱粉濃度を操作すること で澱粉を所定の平均粒子径まで微細化することが示唆 された。また，大気圧 $-100^{\circ} \mathrm{C} て ゙$ 処理した場合に打いて は $100 \mathrm{~nm}$ 以下に分布を確認できず，加圧熱水を用いて 調製した場合にはいずれの試料に扔いても $100 \mathrm{~nm}$ 以下 に分布があった。このことから加圧熱水によるナノス ケール微細化は澱粉を粒子径 $100 \mathrm{~nm}$ 以下の小さな粒子 が含まれるように微細化する際に有効な手法であるこ とがわかった，粒度分布の広がりを示す spanには，調 製条件による規則性は見られなかったが，大気圧 $-100^{\circ} \mathrm{C}$ で調製した試料に比べていずれの試料も大きく, 粒度分布の広がりが大きくなった。澱粉ナノ粒子分散 系には粒子径 $100 \mathrm{~nm}$ 以下の小さな粒子から $1000 \mathrm{~nm}$ 程の大きな粒子まで存在しており，粒子径分布が，よ り均一な試料の調製が課題のひとつとしてあげられる. 加圧熱水の反応場のイオン積と調製粒子の平均粒子径 に相関があった。 
謝辞

本研究は，基盤研究 (C) 課題番号 23589157，一部は 食品ナノテクノロジープロジェクトで実施されている ことを記し，謝意を表します。

\section{引 用 文 献}

1) S. F. Chin, S. C. Pang, S. H. Tay; Size controlled synthesis of starch nanoparticles by a simple nanoprecipitation method. Carbohydr. Polym., 86, 1817-1819 (2011).

2) H. Okadome; "Micro-nano scale pulverization of starch based food products and its properties" (in Japanese), S. Adachi, M. Nakajima, S. Sugiyama (eds.), Advances in Nanotechnology for Food Products, CMC Publishing Co., Ltd., Japan, 2013, pp. 109-119.

3) A. Rodrigues, M. Emeje; Recent applications of starch derivatives in nanodrug delivery. Carbohydr. Polym., 87, 987-994 (2012).

4) D. M. A. M. Luykx, R. J. B. Peters, S. M. van Ruth, H. Bouwmeester; A review of analytical methods for identification and characterization of nano delivery systems in food. J. Agric. Food Chem., 56, 8231-8247 (2008).

5) N. Sozer, J. L. Kokini; Nanotechnology and its applications in the food sector. Trends Biotechnol., 27, 82-89 (2009).

6) V. J. Morris; Emerging roles of engineered nanomaterials in the food industry. Trends Biotechnol., 29, 509-516 (2011).

7) F. Chivrac, Ericpollet, L. Averous; Progress in nano-biocomposites based on polysaccharides and nanoclays. Mater. Sci. Eng., 67, 1-17 (2009).

8) H. Angellier, S. Molina-Boisseau, P. Dole, A. Dufresne; Thermoplastic starch-waxy maize starch nanocrystals nanocomposites. Biomacromol., 7, 531-539 (2006).

9) S. Saito; Rice starch and rice powder as materials for food industry (in Japanese). Denpun Kagaku, 27, 295-313 (1980).

10) Y. Kaneko, J. Kadokawa; Biomacromolecules as organic resources (in Japanese). Nippon Gomu Kyokaishi, 81, 3 (2008).

11) D. L. Corre, J. Bras, A. Dufresne; Starch nanoparticles: A review. Biomacromol., 11, 1139-1153 (2010).

12) S. Ueno, M. Anzai, T. Shigematsu, T. Fujii; Kinetic analysis of partial decomposition of starch in hot-compressed water (in Japanese). Jpn. J. Food Eng., 9, 143-150 (2008).

13) W. F. Marshall, E. U. Franck; Ion product of water substance, $0-10000^{\circ} \mathrm{C}, 1-10000$ bars, new international formulation and its background. J. Phys. Chem. Ref. Data, 10, 295-304 (1981).

14) S. Adachi; Subcritical fluid: Its properties and utilization (in Japanese). Kagaku to Seibutsu, 47, 697-702 (2009).

15) T. Mizuno; Properties and application of supercritical water (in Japanese). Zairyou to Kankyou, 47, 298-305 (1998).

16) C. Tokoro, Y. Okano, H. Sasaki; Coagulation kinetics of monodispersed polystyrene latex particles by dynamic light scattering method (in Japanese). Shigen to Sozai, 116, 193197 (2000).

17) E. P. Herrero, E. M. Martín Del Valle, M. A. Galán, Modelling prediction of the microcapsule size of polyelectrolyte complexes produced by atomization. Chem. Eng. J., 121, 1-8 (2001).

18) S. Podzimek; "Light scattering, size exclusion chromatography and asymmetric flow field flow fraction”, John Wiley \& Sons, Inc. Publication, USA, 2011, pp. 59-63.

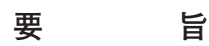

加圧熱水の反応場を用いてモチ米澱粉のナノスケー ル化を行った。澱粉の濃度，加圧熱水の圧力と温度を それぞれ操作し，調製条件の違いによる澱粉粒子の性 質の違いを観察した。澱粉粒子の性質としてゼータ電 位・粒度分布測定装置を用いて平均粒子径と粒子径分 布を測定した。澱粉の平均粒子径は調製条件に依存し， 濃度が小さいほど平均粒子径は小さくなり，圧力と温 度が高いほど平均粒子径は小さくなった. 濃度 $0.1 \%$ (w/ w), 初期圧力 $3.0 \mathrm{MPa}$, 到達温度 $180^{\circ} \mathrm{C}$ という調製条件 において平均粒子径が $150.4 \mathrm{~nm}$ となり，本実験におけ る最小の平均粒子径を示すことが明らかになった。ま た，100 nm 以下の粒子が約 $30 \%$ であった。本実験の操 作範囲に打いて温度，圧力および濃度を操作すること で平均粒子径を制御し，目的に応じた平均粒子径の試 料を調製できることが示唆された。 また，大気圧 $-100^{\circ} \mathrm{C}$ で調製した場合においては $100 \mathrm{~nm}$ 以下の成分が 確認できず，加圧熱水を用いて調製した場合ではいず れの試料に扔いても $100 \mathrm{~nm}$ 以下に粒子の分布が認めら れた。 このことから加圧熱水は平均粒子径 $100 \mathrm{~nm}$ 以下 の小さな粒子を調製する手段として有効であることが わかった。 さらに，圧力と温度から Marshall-Franck の式を用いて求めた水のイオン積によって，加圧熱水 の反応場の特性を評価できることが明らかになった。 